\title{
Can Oral hypoglycemic drugs replace Insulin for management of patients with gestational diabetes mellitus in pregnant Egyptian women's? Observational study:
}

\begin{abstract}
Objectives: is to evaluate Insulin, Metformin and Glibenclamide in control of gestational diabetes mellitus.

Background: Gestational diabetes mellitus [GDM] is a common complication of pregnancy. Blood glucose control improves perinatal outcomes. Medical nutrition therapy is the milestone management.

Methods: In our prospective observational cohort comparative study, 360 patients with GDM who did not controlled by diet alone who were attending at clinics at Obstetrics Department in Menoufia University Hospitals from November 2016 to November 2017. They were separated into three groups, group 1 contain 120 patient received insulin, group 2 contain 120 patient received metformin, group 3 contain 120 patient received glibenclamide. We compared the results of maternal glucose level, maternal complications and neonatal outcome in each group.
\end{abstract}

Results: We found no significant change in blood sugar control, maternal complications or neonatal results with the use of insulin, metformin or glibenclamide.

Conclusion: Good glycaemic results in GDM can occur by giving glibenclamide or metformin with similar risk of maternal complications and fetal outcome to use of insulin. So oral hypoglycemic drugs can replace insulin in cases with GDM in pregnant Egyptian womens.

Keywords: insulin, metformin, glibenclamide, glucose tolerance test, gestational diabetes Mellitus

Abbreviations: GDM, gestational diabetes mellitus; NICE, National institute for health and clinical excellence; ADA, American diabetic association; FBG, Fasting blood glucose; RCTs, randomized controlled trials

\section{Introduction}

Gestational diabetes mellitus [GDM] is diagnosed when glucose intolerance starts during pregnancy. ${ }^{1}$ It occurs in $6-7 \%$ of pregnancies. These patients have more chance of maternal complications and developing diabetes in older age with many neonatal complications up to stillbirth and neonatal death..$^{2,3}$ Use of insulin has been the only pharmacological line for women with GDM, but it is high cost and inconvenient. ${ }^{1}$ Many studies show that Glibenclamide and metformin can be used as insulin in controlling hyperglycemia in GDM, with no change in maternal and neonatal complications. ${ }^{4}$ The target of our study is to evaluate use of metformin or glibenclamide in glycemic control and reducing maternal and neonatal complications in GDM to assess if it is possible to replace metformin or glibenclamide instead of insulin in GDM.

\section{Materials and methods}

It is a prospective observational chort comparative study. After obtaining an approval from Hospital Local Medical Ethics Committee, Three hundred and sixty patients (360 patients) with GDM and not controlled by diet modifications or nutritional instructions alone in 2 weeks who were attending at clinics at Obstetrics Department in Menoufia University Hospitals November 2016 to November 2017. GDM was diagnosed according to American Diabetic Association
Volume 8 Issue 5 - 2019

\author{
Ibrahim Saif Elnasr, Hesham Ammar \\ Department of obstetrics and gynecology, university of \\ Menoufia Governorate, Egypt
}

Correspondence: Ibrahim Saif Elnasr, Department of obstetrics and gynecology, Faculty of Medicine, University of Menoufia Governorate, Egypt, Tel +20I 003086747 , Email lbrahimalisaifelnasr@gmail.com

Received: August 18,2019| Published:September 10, 2019
[ADA] at 24-28weeks if blood glucose values in excess of: Fasting: $>92 \mathrm{mg} / \mathrm{dL} \quad[5.1 \mathrm{mmol} / \mathrm{L}], \quad 1 \mathrm{~h}:>180 \mathrm{mg} / \mathrm{dL} \quad[10.0 \mathrm{mmol} / \mathrm{L}]$, $2 \mathrm{~h}:>153 \mathrm{mg} / \mathrm{dL}[8.5 \mathrm{mmol} / \mathrm{L}] .^{5}$ In our study we excluded multiple pregnancies, Pre-pregnancy diagnosis of diabetes, Contraindications to metformin as renal impairment, Contraindication to Sulfonylurea as hepatic impairment, fetal anomaly or fetal growth restrictions, Gestational hypertension or pre-eclampsia. Our work was explained to the patients before obtaining the verbal and written informed consents. Patients were separated into three groups. One hundred and twenty pregnant mothers in each group.

1st group (120 patients): Received insulin in form of mixed insulin [Mixtard $\AA$, Novo Norisk]. The starting dose was 0.7 unit $/ \mathrm{kg}$ of actual body weight, given subcutaneously twice daily increased weekly as necessary.

2nd group (120 patients): Received metformin in form of [Cidophage ${ }^{\circledR}, 850 \mathrm{mg}$, Cid] in dose of $850 \mathrm{mg}$ once daily increased by $500 \mathrm{mg}$ weekly if necessary to achieve glycemic control up to $2500 \mathrm{mg}$ maximum dose.

3rd group (120 patients): Received Glibenclamide in form of [Doanil ${ }^{\circledR}, 5 \mathrm{mg}$, Aventis pharma]. The starting dose was $2.5 \mathrm{mg}$ orally in the morning; it was increased by $2.5 \mathrm{mg}$ weekly when necessary to achieve glycemic control up to total of $20 \mathrm{mg}$ maximum dose.

Self-monitoring was assessed using measurement of sugar levels in blood. Fasting and 2hour postprandial blood glucose had been measured with the 3 main meals.Patients were shifted to insulin therapy if glycemic control not achieved by maximum dose of metformin or glibenclamide. Primary outcome was to achieve glycemic control 
according to National institute for Health and Clinical Excellence [NICE [revised 2015]]: Fasting blood glucose [FBG] level: $<95.4 \mathrm{mg} /$ $\mathrm{dl}, 1 \mathrm{~h}$ postprandial blood glucose level: $<140 \mathrm{mg} / \mathrm{dl}, 2 \mathrm{~h}$ postprandial blood glucose level: $<115 \mathrm{mg} / \mathrm{dl}$. Keeping pregnant women with Diabetes who are on insulin or glibenclamide to maintain their capillary plasma glucose level above $72 \mathrm{mg} / \mathrm{dl}$. Secondary outcomes were Hypertensive complications (gestational hypertension or preeclampsia). ,Maternal hypoglycemia, Preterm lobour and mode of delivery, Neonatal hypoglycemia, Macrosomia , Lung complications or need for phototherapy, Admission to neonatal intensive care unit and presence of congenital anomalies. Dose modifications of drugs were made at each antenatal visit weekly till delivery. Antenatal care was done at the outpatient clinics. Ultrasound examination was done at first visit for dating and at 16-19weeks for congenital anomaly scanning and every month from 28 weeks to assess well-being of fetus. Patients had HbAIC measurement at first visit and at 37weeks. Glycemic control, medical complications, mode of delivery, and neonatal outcomes were documented and statistically analyzed.

\section{Statistical analysis}

Our results were collected and analyzed by an IBM compatible personal computer with SPSS statistical package version 20 (SPSS Inc. released 2011. IBM SPSS statistics for windows, version 20.0, Armonk, NY: IBM Corp.). Quantitative data were expressed as mean $\pm \mathrm{SD}$ while qualitative data were expressed as numbers and percentages (\%). Student test was done to assess importance of change for quantitative variables and Chi Square was done to assess importance of change for qualitative variables were less than five, Fischer's Exact test was used for comparison of quantitative variables between more than two groups with non-parametric data. A probability value $p<0.05$ was significant statistically. Data were analyzed and appropriately presented in tables.

\section{Results}

A total of 360 patients with GDM and not controlled by diet modifications or nutritional instructions alone in 2 weeks were included in our work. Women were divided to treatment with insulin, Metformin or Glibenclamide.

Table 1 represent no significant statistical difference between insulin, Metformin or Glibenclamide groups as regarding demographic characteristics at the first visit.

Table 2 \& 3 demonstrate that FBG and 2-hour postprandial blood glucose levels had no significant difference in three groups. Glycemic targets were similar throughout pregnancy with no significant difference in the studied groups.

Table 4 represent no statistical difference had occurred in the studied groups according to medical and obstetric disorders which developed during antenatal period as regard to gestational hypertension, pre-eclampsia, hypoglycemia, and preterm labor. Also no statistical difference had occurred in the studied groups according to mode of delivery

Table 5 demonstrate no statistical difference had occurred in the studied groups according to neonatal outcome as regard to neonatal hypoglycemia, macrosomia, 5min Apgar score less than 7, respiratory distress syndrome, admission to neonatal intensive unit or need to phototherapy.

Table I Comparison between the studied groups according to socio-demographic characters

\begin{tabular}{|c|c|c|c|c|c|c|c|c|c|}
\hline & \multicolumn{2}{|c|}{ Group I [Insulin] } & \multicolumn{2}{|c|}{$\begin{array}{l}\text { Group II } \\
\text { [Metformin] }\end{array}$} & \multicolumn{2}{|c|}{$\begin{array}{l}\text { Group III } \\
\text { [Glibenclamide] }\end{array}$} & \multirow{2}{*}{$\begin{array}{l}\text { Test of } \\
\text { sig. }\end{array}$} & \multirow{2}{*}{$\begin{array}{l}\mathbf{P} \text { value } \\
0.82\end{array}$} & \multirow{2}{*}{$\begin{array}{l}\text { Post hoc } \\
\text { test }\end{array}$} \\
\hline Age: [Mean \pm SD*] & \multicolumn{2}{|c|}{$30.2 \pm 5.6$} & \multicolumn{2}{|c|}{$31.9 \pm 2.9$} & \multicolumn{2}{|c|}{$31.8 \pm 3.7$} & & & \\
\hline Parity & No & $\%$ & No & $\%$ & No & $\%$ & & & \\
\hline I & 8 & 6.7 & 10 & 8.3 & 11 & 9.1 & & & \\
\hline 2 & 40 & 33.3 & 38 & 31.6 & 56 & 46.7 & & & \\
\hline 3 & 40 & 33.3 & 43 & 35.8 & 34 & 28.3 & & 0.00 & 1.00 \\
\hline 4 & 32 & 26.7 & 29 & 24.1 & 16 & 13.3 & & & \\
\hline 5 & 0 & 0.0 & 0 & 0.0 & 3 & 2.5 & & & \\
\hline $\begin{array}{l}\text { Family history of D.M.* [No-\%] } \\
\text { Positive: }\end{array}$ & \multicolumn{2}{|c|}{14 [II.7\%] } & \multicolumn{2}{|c|}{15 [12.5\%] } & \multicolumn{2}{|c|}{$13[10.8 \%]$} & 0.16 & 0.92 & - \\
\hline Negative: & \multicolumn{2}{|c|}{106 [88.3\%] } & \multicolumn{2}{|c|}{$105[87.5 \%]$} & \multicolumn{2}{|c|}{107 [89.2\%] } & & & \\
\hline $\mathrm{BMI} * *$ at enrollment & \multicolumn{2}{|c|}{$27.6 \pm 1.5$} & \multicolumn{2}{|c|}{$27.7 \pm 2.5$} & \multicolumn{2}{|c|}{$26.8 \pm 1.3$} & 4.2 & 0.19 & - \\
\hline $\begin{array}{l}\text { Gestational age at enrollment } \\
\text { [weeks] }\end{array}$ & \multicolumn{2}{|c|}{$25.5 \pm 1.5$} & \multicolumn{2}{|c|}{$25.7 \pm 1.6$} & \multicolumn{2}{|c|}{$26.1 \pm 2.3$} & 5.1 & 0.29 & - \\
\hline Systolic blood pressure & \multicolumn{2}{|c|}{$113.5 \pm 8.1$} & \multicolumn{2}{|c|}{$114.2 \pm 8.3$} & \multicolumn{2}{|c|}{$114.3 \pm 5.3$} & 1.03 & 0.59 & - \\
\hline Diastolic blood Pressure & \multicolumn{2}{|c|}{$78.1 \pm 5.7$} & \multicolumn{2}{|c|}{$77.6 \pm 5.3$} & \multicolumn{2}{|c|}{$79.1 \pm 4.6$} & 3.92 & 0.14 & - \\
\hline $\begin{array}{l}\text { Fasting blood sugar after } 75 \mathrm{~g} \\
\text { OGTT***[mg/dl] }\end{array}$ & \multicolumn{2}{|c|}{ II $5.4 \pm 5.5$} & \multicolumn{2}{|c|}{$113.20 \pm 4.6$} & \multicolumn{2}{|c|}{$|I| .26 \pm 5.1$} & 1.5 & 0.2 & - \\
\hline $\begin{array}{l}2 \mathrm{~h} \text { postprandial BL sugar after } 75-\mathrm{g} \\
\text { OGTT [mg/dl] }\end{array}$ & \multicolumn{2}{|c|}{$197.31 \pm 9.9$} & \multicolumn{2}{|c|}{$197.20 \pm 9.6$} & \multicolumn{2}{|c|}{$196.13 \pm 10.9$} & 0.1 & 0.9 & - \\
\hline $\mathrm{HbAIC}$ ****at recruitment & \multicolumn{2}{|c|}{$5.2 \pm 0.31$} & \multicolumn{2}{|c|}{$5.4 \pm 0.60$} & \multicolumn{2}{|c|}{$5.30 \pm 63$} & 5.07 & 0.07 & - \\
\hline
\end{tabular}

*: standard deviation * Diabetes mellitus ** Body mass Index *** Oral glucose tolerance test **** Hemoglobin AIC 
Table 2 Comparison between the three studied groups according to fasting blood sugar

\begin{tabular}{|c|c|c|c|c|c|c|}
\hline & $\begin{array}{l}\text { Group I (Insulin) } \\
\text { Mean士SD* }\end{array}$ & $\begin{array}{l}\text { Group II } \\
\text { (Metformin) } \\
\text { mean } \pm \text { SD* }\end{array}$ & $\begin{array}{l}\text { Group III } \\
\text { (Glibenclamide) } \\
\text { Mean士SD* }\end{array}$ & $\begin{array}{l}\text { Test of } \\
\text { sig }\end{array}$ & $P$ value & $\begin{array}{l}\text { Post hoc } \\
\text { test }\end{array}$ \\
\hline $\begin{array}{l}\text { FBS* throughout treatment } \\
\mathrm{mg} / \mathrm{dl}\end{array}$ & $92.70 \pm 5.8$ & $93.88 \pm 6.2$ & $94.08 \pm 8.9$ & 2.8 & 0.07 & - \\
\hline $\begin{array}{l}\text { FBS before } 2 \text { weeks of delivery } \\
\mathrm{mg} / \mathrm{dl}\end{array}$ & $92.05 \pm 5.3$ & $92.42 \pm 6.01$ & $93.41 \pm 8.5$ & 1.2 & 0.2 & - \\
\hline
\end{tabular}

* Fasting blood sugar *: standard deviation

Table 3 Comparison between the three studied groups according to $2 \mathrm{~h}$ postprandial $\mathrm{BL}$ sugar

\begin{tabular}{|c|c|c|c|c|c|c|}
\hline & $\begin{array}{l}\text { Group-I } \\
\text { (Insulin) } \\
\text { Mean士SD* }\end{array}$ & $\begin{array}{l}\text { Group-II } \\
\text { (Metformin) } \\
\text { Mean士SD* }\end{array}$ & $\begin{array}{l}\text { Group-III } \\
\text { (Glibnclamide) } \\
\text { Mean士SD* }\end{array}$ & $\begin{array}{l}\text { Test of } \\
\text { sig }\end{array}$ & $P$ value & $\begin{array}{l}\text { Post hoc } \\
\text { test }\end{array}$ \\
\hline $\begin{array}{l}\text { 2hppBS* level throughout treatment } \\
{[\mathrm{mg} / \mathrm{dl}]}\end{array}$ & || $7.6 \mid \pm 6.2$ & I I7.99 44.4 & $118.06 \pm 3.8$ & 0.1 & 0.86 & - \\
\hline $\begin{array}{l}\text { 2hppBS level } 2 \text { weeks before Treatment } \\
{[\mathrm{mg} / \mathrm{dl}]}\end{array}$ & || $5.5 \mid \pm 6.7$ & $116.10 \pm 3.8$ & I $16.27 \pm 64$ & 1.9 & 0.2 & - \\
\hline
\end{tabular}

*2 hour post prandial blood sugar *: standard deviation

Table 4 Maternal outcomes in the study groups

\begin{tabular}{|c|c|c|c|c|c|c|}
\hline & & $\begin{array}{l}\text { Group I (Insulin) } \\
\text { No (\%) }\end{array}$ & $\begin{array}{l}\text { Group II } \\
\text { (Metformin) No } \\
(\%)\end{array}$ & $\begin{array}{l}\text { Group III } \\
\text { (Glibenclamide) } \\
\text { No (\%) }\end{array}$ & $\begin{array}{l}\text { Test of sig. } \\
\mathbf{x}^{2}\end{array}$ & P value \\
\hline \multirow{2}{*}{$\begin{array}{l}\text { Gestational } \\
\text { hypertension }\end{array}$} & +ve & $8(6.7 \%)$ & $7(5.8 \%)$ & $8(6.7 \%)$ & 0.09 & 0.95 \\
\hline & -ve & $112(93.3 \%)$ & II3(94.2.\%) & $112(93.3 \%)$ & & \\
\hline \multirow[t]{2}{*}{ Preeclampsia } & $+v e$ & $9(7.5 \%)$ & $10(8.3 \%)$ & $\mathrm{II}(9.2 \%)$ & 0.2 & 0.89 \\
\hline & -ve & I I I(92.5\%) & $110(91.7 \%)$ & $109(90.8 \%)$ & & \\
\hline \multirow[t]{2}{*}{ Maternal hypoglycemia } & +ve & $15(12.5 \%)$ & $5(4.2 \%)$ & $5(4.2 \%)$ & 3.2 & 0.2 \\
\hline & -ve & $105(87.5 \%)$ & II5(95.8\%) & II5(95.8\%) & & \\
\hline \multirow[t]{2}{*}{ Preterm delivery } & +ve & $9(7.5 \%)$ & $13(10.8 \%)$ & $10(8.3 \%)$ & 0.9 & 0.64 \\
\hline & -ve & | I | (92.5\%) & $107(89.2 \%)$ & $110(91.7 \%)$ & & \\
\hline \multirow[t]{2}{*}{ Mode of delivery } & NVD* & $45(37.5 \%)$ & $43(35.8 \%)$ & $44(36.7 \%)$ & 0.7 & 0.96 \\
\hline & $\operatorname{CS}^{x}$ & $75(62.5 \%)$ & $77(64.2 \%)$ & $76(63.3 \%)$ & & \\
\hline
\end{tabular}

* Normal vaginal delivery ${ }^{\times} 2$ Cesarean section

Table 5 Neonatal outcomes in the study groups

\begin{tabular}{|c|c|c|c|c|c|c|}
\hline & & $\begin{array}{l}\text { Group I } \\
\text { (insulin) } \\
\text { No(\%) }\end{array}$ & $\begin{array}{l}\text { Group II } \\
\text { (Metformin) No } \\
(\%)\end{array}$ & $\begin{array}{l}\text { Group III } \\
\text { (Glibenclamide) } \\
\text { No (\%) }\end{array}$ & $\begin{array}{l}\text { Test of sig. } \\
x^{2}\end{array}$ & $P$ value \\
\hline \multirow[t]{2}{*}{ Neonatal hypoglycemia } & + ve & $52(43.3 \%)$ & $28(23.3 \%)$ & $24(20 \%)$ & 4.7 & 0.1 \\
\hline & -ve & $68(56.7 \%)$ & $92(76.7 \%)$ & $96(80 \%)$ & & \\
\hline \multirow[t]{2}{*}{ Macrosomia } & + ve & $19(15.8 \%)$ & $17(\mid 4.2 \%)$ & $15(12.5 \%)$ & 0.5 & 0.7 \\
\hline & -ve & $101(84.2 \%)$ & $103(85.5 \%)$ & $105(87.5 \%)$ & & \\
\hline \multirow[t]{2}{*}{ 5-min Apgar score $<7$} & + ve & $2(1.7 \%)$ & $3(2.5 \%)$ & $\mathrm{I}(0.8 \%)$ & 1 & 0.6 \\
\hline & -ve & II8(98.3\%) & II7(97.5\%) & II9(99.2\%) & & \\
\hline
\end{tabular}

Citation: Elnasr IS, Ammar H. Can Oral hypoglycemic drugs replace Insulin for management of patients with gestational diabetes mellitus in pregnant Egyptian women's? Observational study: MOJWomen's Health. 2019;8(5):269-273. DOI: I0.15406/mojwh.2019.08.00249 


\begin{tabular}{|c|c|c|c|c|c|c|}
\hline & & $\begin{array}{l}\text { Group I } \\
\text { (insulin) } \\
\text { No(\%) }\end{array}$ & $\begin{array}{l}\text { Group II } \\
\text { (Metformin) No } \\
\text { (\%) }\end{array}$ & $\begin{array}{l}\text { Group III } \\
\text { (Glibenclamide) } \\
\text { No (\%) }\end{array}$ & $\begin{array}{l}\text { Test of sig. } \\
x^{2}\end{array}$ & $P$ value \\
\hline \multirow[t]{2}{*}{ Respiratory distress syndrome } & $+\mathrm{ve}$ & $8(6.7 \%)$ & $7(5.8 \%)$ & $6(5 \%)$ & 0.3 & 0.8 \\
\hline & -ve & $112(93.3 \%)$ & $113(94.2 \%)$ & II4(95\%) & & \\
\hline \multirow[t]{2}{*}{ Phototherapy } & $+\mathrm{ve}$ & $19(15.8 \%)$ & $23(19.2 \%)$ & $16(13.3 \%)$ & 1.5 & 0.5 \\
\hline & -ve & $101(84.2 \%)$ & $97(80.8 \%)$ & $104(86.7 \%)$ & & \\
\hline \multirow[t]{2}{*}{ NICU admission* } & $+\mathrm{ve}$ & $22(18.3 \%)$ & $20(16.7 \%)$ & $21(17.5 \%)$ & & \\
\hline & -ve & $98(81.7 \%)$ & $100(83.3 \%)$ & $99(82.5 \%)$ & 1 & 0.6 \\
\hline
\end{tabular}

* Neonatal intensive care unit

\section{Discussion}

Gestational diabetes mellitus [GDM] has been defined as glucose intolerance of any degree with first diagnosis during pregnancy. It complicated $1-14 \%$ of all pregnant women. ${ }^{6}$ It is common medical complication of pregnancy which can result in variable adverse effects to mother and increased possibility of prenatal morbidity. ${ }^{7}$ First line of treatment consists of self-monitoring of blood sugar levels, diet control and physical exercise. Pharmacological therapy is indicated when first line of treatment fail to control blood sugar during pregnancy. ${ }^{8}$

Pharmacological therapy for pregnant women is related to its risk on fetus which depends on passage through placenta and if it has adverse impact on the fetus or not. Many drugs given during pregnancy pass through the placenta and may have no effects on the fetus. ${ }^{9}$ For a long time, insulin has been the first-line drug therapy of GDM with no fetal obstacles. ${ }^{10}$ Main problems of insulin use are: requirement of health education, need of multiple daily injections, and need of dose change according to body mass index, incidence of hypoglycemia, and weight increase in pregnant woman. So, oral therapy would be more suitable for patients. ${ }^{11}$ The fear of using glibenclamide and metformin in pregnancy is caused by concerns about their effect on the fetus. ${ }^{12}$ Many studies was done to detect the extent of transplacental cross of glibenclamide; Kraemer et al. ${ }^{13}$ detected active transport of glibenclamide from the fetal circulation to the mother that may protect the fetus from the drug contact. Langer et al. ${ }^{14}$ found no glibenclamide in the umbilical cord blood in spite of its presence in mother blood. Others found that fetal levels of glibenclamide can be $1 \%$ to $2 \%$ of mother concentration..$^{15}$ Moore et al. ${ }^{16}$ found no statistical difference in neonatal results of patients with GDM that were managed by metformin to those with glibenclamide.

Our study results had no significant difference in comparison to studies done by Coetzee and Jackson in 1970. Coetzee and Jackson were the first researchers who studied possibility of use of metformin in pregnancy in patients with insulin-independent diabetes. Their research had two groups of patients; the first group managed by metformin and the second one managed by insulin. The maternal and perinatal results were similar in both groups. ${ }^{17} \mathrm{Lim}$ et al.${ }^{18}$ was the first researcher who detected that oral hypoglycemic drugs can treat GDM efficiently and securely with no difference in pregnancy outcomes. In 2000, Hellmuth et al. ${ }^{19}$ had a cohort study of type 2DM pregnant women on glibenclamide in comparison to metformin versus insulin. Their results proposed superiority of metformin use due to increase of preeclampsia [32\% metformin versus $7 \%$ glibenclamide versus $10 \%$ insulin] and intrauterine fetal death [ $8 \%$ versus $0 \%$ versus $2.3 \%$, correspondingly]. Later on, this work has become controversial as reviewers found that patients in the study were not sound matched. As patients who were managed by metformin were morbidly obese and started to use the medication later on in the pregnancy. So the patients were at higher risk for bad pregnancy complications not related to metformin use. ${ }^{20}$

Langer et al. ${ }^{14}$ in a their study conducted on 404 women with GDM who were randomized to receive either glibenclamide [upto $20 \mathrm{mg}$ / day] or insulin, found that the result of glycemic control was the same in both groups with no significant difference concerning maternal or neonatal outcome. Rowan et al. ${ }^{21}$ performed a study on patients with GDM managed by insulin or metformin. There was no statistical difference in results of both groups in controlling sugar levels. Infants of metformin group had less incidence of hypoglycemia compared with other group with no more neonatal complications.

Nowadays, many studies focus on detection of results of oral anti diabetic drugs when used in treatment of GDM. Some studies are case-control trials and others are observational..$^{22}$ The randomized controlled trials [RCTs] have small samples which cannot represent valid conclusion about the use of oral drugs for managing GDM.

\section{Limitation of our study}

Inability to recruit a large number of patients and to design a multicenter randomized trial was unintended limitation of current study. Future research should focus on inexpensive, available and easily applicable drugs for management of GDM is warranted.

\section{Strength of the study}

Our study is promising for management of GDM with cheap, available and easily applicable oral hypoglycemic drugs instead of traditional insulin; accordingly such pregnant women will have good life style with less injection trials.

\section{Conclusion}

According to the current study, metformin and glibenclamide are safe and useful, especially for patients with mild to moderate hyperglycemia and do not desire multiple daily insulin injections. Moreover, they offer a simple, inexpensive and convenient alternative to insulin in such individuals.

\section{Authors contribution}

Ibrahim Saif Elnasr: Study design, Interpretation of data and paper writing and paper submission.

Hesham Ammar: Data collection and follow up of cases and paper writing. 


\section{Acknowledgments}

The authors would like to acknowledge the contribution of patients, residents and nursing staff at the outpatient's clinic of Menoufia University hospital.

\section{Conflicts of interest}

The author declares that there are no conflicts of interest.

\section{References}

1. Dhulkotia JS, Ola B, Fraser R, et al. Oral hypoglycemic agent's vs insulin in management of gestational diabetes: a systematic review and meta-analysis. Am J Obstet Gynecol. 2010;203(5):457-461.

2. Landon MB, Gabbe SG. Gestational diabetes mellitus. Obstet Gynecol. 2011;118:1379-1393.

3. Lowe LP, Metzger BE, Dyer AR, et al. Hyperglycemia and Adverse Pregnancy Outcome [HAPO] Study: associations of maternal HbA1C and glucose with pregnancy outcomes. Diabetes Care. 2012;35(3):574580

4. Zeng YC, Li MJ, Chen Y, et al. The use of glyburide in the management of gestational diabetes mellitus: a meta-analysis. $A d v$ Med Sci 2014;59(1):95-101.

5. American Diabetes Association. Lifestyle Management: Standards of medical care in diabetes. Diabetes Care. 2014;37(1):S46-S60.

6. American Diabetes Association. Diagnosis and classification of diabetes mellitus. Diabetes Care. 2010;33(1):S81-S90.

7. Horvath K, Koch K, Jeitler K. Effects of treatment in women with gestational diabetes mellitus: systematic review and meta-analysis. British Medical Journal, 2010;340:796-801.

8. Crowther CA, Hiller JE, Moss JR, et al. Effect of treatment of gestational diabetes mellitus on pregnancy outcomes. $N$ Engl J Med. 2005;352:2477-2486.

9. American Diabetes Association. Diagnosis and classification of diabetes mellitus. Diabetes Care. 2006;30:S42-S47.
10. Ziegler MH, Grafton TF, Hansen DK. The effect of tolbutamide on rat embryonic development in vitro. Teratology. 1993;48(1):45-51.

11. Metzger BE, Lowe LP, Dyer AR. Hyperglycemia and adverse pregnancy outcomes. N Engl J Med. 2008;358(19):1991-2002.

12. Committee on Practice Bulletins--Obstetrics. Practice Bulletin No.137: Gestational diabetes mellitus. Obstet Gynecol. 2013;122:406-416.

13. Kraemer J, Klein J, Lubetsky A, et al. Perfusion studies of glyburide transfer across the human placenta: implications for fetal safety. Am $J$ Obstet Gynecol. 2006;195:270-274.

14. Langer $\mathrm{O}$, Conway DL, Berkus MD, et al. A comparison of glyburide and insulin in women with gestational diabetes mellitus. $N$ Engl $J$ Med. 2000;343(16):1134-1138.

15. Nanovskaya TN, Nekhayeva I, Hankins GD, et al. Effect of human serum albumin on transplacental transfer of glyburide. Biochem Pharmacol. 2006;72(5):632-639.

16. Moore LE, Clokey D, Rappaport VJ, et al. Metformin compared with glyburide in gestational diabetes: a randomized controlled trial. Obstet Gynecol. 2010;115(1):55-59

17. Coetzee EJ, Jackson WP. The management of non-insulin DM in pregnancy. Diabetes Res Clin Pract. 1986;1(5):281-287.

18. Lim YJ, Tayob PM, Shaw RW. A comparison between the pregnancy outcome of women with gestation diabetes treated with glibenclamide and those treated with insulin. Med J Malaysia. 1997;52(4):377-381.

19. Hellmuth E, Damm P, Mosted-Pedersen L. Oral hypoglycemic agents in 118 diabetic pregnancies. Diabet Med. 2000;17(7):507-511.

20. Norman RJ, Wang JX, Hague W. Should we continue or stop insulinsensitizing drugs during pregnancy? Curr Opin Obstet Gynecol. 2004;16(3):245-250.

21. Rowan JA, Hague WM, Gao W, et al. Metformin versus insulin for the treatment of gestational diabetes. N Engl J Med. 2008;358(19):20032015 .

22. Goh JE, Sadler L, Rowan J. Metformin for gestational diabetes in routine clinical practice. Diabet Med. 2011;28(9):1082-1087. 